DINIZ, Silvania Aparecida; LUZ, Cícero Krupp da. Benefício de prestação continuada aos imigrantes e a decisão do recurso extraordinário 587970 do STF: direito ou calvário? Revista Eletrônica Direito e Política, Programa de Pós-Graduação Stricto Sensu em Ciência Jurídica da UNIVALI, Itajaí, v.13, n.3, $3^{\circ}$ quadrimestre de 2018. Disponível em: www.univali.br/direitoepolitica - ISSN 1980-7791

\title{
BENEFÍCIO DE PRESTAÇÃO CONTINUADA AOS IMIGRANTES E A DECISÃO DO RECURSO EXTRAORDINÁRIO 587970 DO STF: DIREITO OU CALVÁRIO?
}

\author{
BENEFIT OF CONTINUED PROVISION TO IMMIGRANTS AND THE DECISION OF \\ EXTRAORDINARY REMEDY 587970 OF THE STF: RIGHT OR CALVARY?
}

Silvania Aparecida Diniz ${ }^{1}$

Cícero Krupp da Luz $^{2}$

SUMÁRIO: Introdução; 10 direito fundamental social do benefício de prestação continuada; 2 A legitimação e a violação do direito de Assistência Social aos estrangeiros no Brasil; 3 Considerações sobre o RE 587970/STF; 4 Direito ou calvário?; Considerações finais; Referências das fontes citadas.

\section{RESUMO}

A Lei Orgânica de Assistência Social no contexto de proteção universal da dignidade humana, é no cenário das migrações sociais, institucionalizadora da proteção dos imigrantes. Recentemente em 22/09/2017, o Supremo Tribunal Federal conferiu aos imigrantes o direito ao benefício de assistência social, na forma de prestação continuada (assumindo consequentes obrigações). Nesse viés, o presente trabalho busca analisar a eficácia das normas jurídicas da assistência social destinada aos imigrantes, através de uma pesquisa explicativa com enfoque na decisão do STF, onde se verifica que os imigrantes são legitimados à percepção das prestações assistenciais, mas encontram barreiras na aferição do critério de

\footnotetext{
1 Mestranda em Constitucionalismo e Democracia pela Faculdade de Direito do Sul de Minas (2016/2018). Professora das disciplinas PPSBI e PPSBII do Curso de Pós-graduação em Direito Material e Processual Previdenciário da PUC/MG (BH). Pós-graduada em Direito Previdenciário pelo Instituto Nacional de Ensino Superior e Pesquisa - Faculdade INESP (2015). Membro da Comissão de Direito Previdenciário da OAB/MG, Presidente da Comissão de Direito Previdenciário da 17a Subseção da OAB/MG (triênio 2013/2015). Coordenadora Adjunta no Sul de Minas do Instituto Brasileiro de Direito Previdenciário (IBDP) e Advogada atuante na área do Direito previdenciário. E-mail: advsilvaniadiniz@gmail.com

2 Doutor em Relações Internacionais pela Universidade de São Paulo - USP (Bolsa FAPESP). Pesquisador visitante da Sciences Po Paris - LInstitut dÉtudes Politiques - IEP. Mestre em Direito Público e Bacharel em Direito pela Universidade do Vale do Rio dos Sinos - UNISINOS (Bolsa CNPq). Participante do Programa da Fundação Friedrich-Ebert-Stiftung para Cooperação Estratégica entre Brasil e União Europeia; Professor da Graduação e do Mestrado em Constitucionalismo e Democracia da Faculdade de Direito do Sul de Minas - FDSM. Professor de Relações Internacionais e de Ciências Econômicas na Fundação Escola de Comércio Álvares Penteado - FECAP. Professor e pesquisador na área de Direito Internacional e Relações Internacionais, com ênfase em globalização, direitos humanos, imigrações e União Europeia. Advogado atuante área de direito administrativo e direito internacional (público e privado) E- mail: ciceroluz@gmail.com
} 
DINIZ, Silvania Aparecida; LUZ, Cícero Krupp da. Benefício de prestação continuada aos imigrantes e a decisão do recurso extraordinário 587970 do STF: direito ou calvário? Revista Eletrônica Direito e Política, Programa de Pós-Graduação Stricto Sensu em Ciência Jurídica da UNIVALI, Itajaí, v.13, n.3, $3^{\circ}$ quadrimestre de 2018. Disponível em: www.univali.br/direitoepolitica - ISSN 1980-7791

nacionalidade no ordenamento jurídico interno do INSS, impedindo o direito de usufruir o referido benefício, mesmo que seja direito consagrado na Constituição brasileira, na legislação interna e nos pactos internacionais, ensejando a necessidade do combate à discriminação entre nacionais e estrangeiros na ordem administrativa da autarquia previdenciária.

Palavras-chaves: Benefício de Prestação Continuada - Imigrantes - Recurso Extraordinário 587970/ STF

\section{ABSTRACT}

The Organic Law of Social Assistance in the context of universal protection of human dignity, is in the scenario of social migrations, institutionalizing the protection of immigrants. Recently on 09/22/2017, the Federal Supreme Court granted immigrants the right to receive social assistance, in the form of a continuous benefit (assuming consequent obligations). In this bias, the present study seeks to analyze the effectiveness of the legal norms of social assistance for immigrants, through an explanatory research focusing on the STF decision, where it is verified that foreigners are legitimated to the perception of welfare benefits, but find barriers in nationality criterion in the INSS legal system, preventing the right to benefit from this benefit, even if it is a right enshrined in the Brazilian Constitution, domestic legislation and international pacts, proving the need to combat discrimination between nationals and administrative order of the social security authority.

Keywords: Benefit of continued provision - Immigrants - Extraordinary Remedy 587970 / STF

\section{INTRODUÇÃO}

Fale com a Previdência Social na central 135, ou acesse o site meu INSS, cadastre seu login e senha, tenha em mãos seus documentos pessoais, ou compareça pessoalmente a uma agência da Previdência Social. Essa é informação prestada pela Previdência Social para o requerimento do benefício assistencial. Acessando o portal da previdência social, ao invés do meu INSS, não encontrará a opção de requerimento de benefício assistencial ao imigrante, somente a opção benefício assistencial ao portador de deficiência e ao idoso, que de plano informa o atendimento como presencial. Sendo o imigrante (refugiado, idoso ou deficiente) escolhendo uma dessas opções, deverá preencher a solicitação que inicialmente requer o número do $\mathrm{CPF}^{3}$ ou $\mathrm{NIS}^{4}$. Se ele for beneficiário de algum programa social

\footnotetext{
${ }^{3}$ CPF - Cadrasto de Pessoas Físicas, existente na Receita Federal do Brasil.

${ }^{4}$ NIS - significa Número de Identificação Social. Todo o cidadão com cadastro na previdência social, no Ministério do Trabalho, ou em benefícios sociais possui esse número que pode ser encontrado no cartão cidadão, carteira de trabalho (CTPS) ou cartão do bolsa família responsável pela inscrição do vínculo empregatício com a Previdência Social e entre outros benefícios sociais vinculados a Caixa Econômica Federal.
} 
DINIZ, Silvania Aparecida; LUZ, Cícero Krupp da. Benefício de prestação continuada aos imigrantes e a decisão do recurso extraordinário 587970 do STF: direito ou calvário? Revista Eletrônica Direito e Política, Programa de Pós-Graduação Stricto Sensu em Ciência Jurídica da UNIVALI, Itajaí, v.13, n.3, $3^{\circ}$ quadrimestre de 2018. Disponível em: www.univali.br/direitoepolitica - ISSN 1980-7791

concedido pelo Brasil, a exemplo o "bolsa família", ele terá o número do NIS, se ainda não tiver, será necessário comparecer perante o CRAS (Centro de Referência de Assistência Social) mais próximo da sua residência para se cadastrar no programa assistencial do governo federal e receber orientações sobre o cadastro de NIS e CPF e ou preencher o formulário de requerimento seja on line ou presencial.

Admitindo-se a hipótese de o imigrante já possuir seu número de inscrição, ao requerer o benefício deverá apresentar toda a documentação pertinente e disposta na legislação (documento de identidade, carteira de trabalho, CPF, NIS, comprovante de endereço, etc.). Se on line, deverá efetuar o envio através de arquivo anexo ao requerimento. Após todo esse caminho e avaliada a documentação apresentada, será determinado uma perícia social, a ser realizada para averiguação da necessidade do requerente.

A presença de imigrantes é parte constituinte do crescimento econômico brasileiro e de nossa vida social. Nos últimos dias, tem sido significante o crescimento da imigração, tais quais os venezuelanos ${ }^{5}$, seja por fatores relacionados ao fenômeno do refúgio (perseguição política e religiosa), seja em busca de melhores condições de vida e trabalho. Tanto o imigrante quanto o refugiado residente no país, inserido na comunidade, participa do esforço mútuo e a responsabilidade pública é assim, compartilhada e múltipla em termos de política pública, tal qual o acesso ao mercado de trabalho, saúde, seguridade social e direitos humanos.

Dessa forma, o Brasil ratificou a Convenção de 1951, por meio do Decreto 50.215 28 de janeiro de 1961, assumindo então a obrigação de se comprometer com esse pacto de Direito Internacional Público, importante instrumento de tutela do Direito dos Refugiados, com a condição de cumpri-la, inclusive quanto à proteção pública, a qual se traduz no âmbito interno em assistência social. Para tanto, a Constituição Federal em seu art. 60, consagrou a assistência aos desamparados como um direito social instituído independentemente de qualquer contribuição, na forma de

\footnotetext{
5 Em razão de crise humanitária do crescente número de imigrantes venezuelanos no Estado do Roraima, o Presidente da República editou a Medida Provisória 820 de 16 de fevereiro de 2018 que dispõe sobre medidas de assistência emergencial para acolhimento a pessoas em situação de vulnerabilidade decorrente de fluxo migratório. Disponível em: <provocado por crise humanitáriabezhttps://www.congressonacional.leg.br/materias/medidas-provisorias//mpv/132234> Acesso em 07 abr. 2018.
} 
DINIZ, Silvania Aparecida; LUZ, Cícero Krupp da. Benefício de prestação continuada aos imigrantes e a decisão do recurso extraordinário 587970 do STF: direito ou calvário? Revista Eletrônica Direito e Política, Programa de Pós-Graduação Stricto Sensu em Ciência Jurídica da UNIVALI, Itajaí, v.13, n.3, $3^{\circ}$ quadrimestre de 2018. Disponível em: www.univali.br/direitoepolitica - ISSN 1980-7791

assistência social, sendo direito de quem dela necessitar. Como corolário, a Lei Orgânica da Assistência Social (LOAS) em seu art. 10, refere-se ao direito do cidadão, e, após a regulamentação pelos Decretos 6.214/07, e 7.617/11, passouse a exigir a naturalização como requisito para a concessão do benefício de prestação continuada ao estrangeiro residente no Brasil. Tais concepções geraram controvérsias quanto ao direito do estrangeiro, notadamente aos imigrantes e refugiados, até que em 22/09/2017 no julgamento do Recurso Especial 587970 pelo Supremo Tribunal Federal em sede de repercussão geral decidiu por afastar a limitação apontada, passando-se a permitir a prestação do referido benefício ao imigrante, destacando que a nacionalidade não é óbice para a concessão do referido benefício (BPC) ${ }^{6}$, quer pela inexistência de vedação constitucional, ou até mesmo por ser o Brasil signatário de tratados internacionais, dentre eles a Declaração Universal dos Direitos Humanos e a Convenção Americana de Direitos Humanos.

Assim, o presente trabalho parte da hipótese que a decisão proferida no RE 587970 pelo STF não tem observância plena na prática, principalmente frente à autarquia previdenciária, que obedece ao fundamento disposto em suas Instruções Normativas internas, tais como a prevista no MDSA/INSS No 1 , de 03 de janeiro de $2017^{7}$, que tem como base a Lei n० 8.742, de 1993 e o Decreto n० 6.214, de 2007, que estabelecem os critérios de nacionalidade e a condição de cidadão, como excludente de direito a concessão do benefício. Assim, o presente artigo pretende discutir a necessidade de uma leitura eficaz da aplicação da decisão do RE 587970, como resultado de uma construção social consequente daqueles que detêm o poder de definição. Assim, buscaremos responder à questão central desta pesquisa que se traduz no questionamento: a decisão proferida no RE 587970 é aplicada no âmbito administrativo pelo gestor - INSS para a concessão do Benefício de Prestação Continuada aos estrangeiros?

\footnotetext{
6 O benefício de prestação continuada é a garantia de um salário-mínimo mensal à pessoa com deficiência e ao idoso com 65 (sessenta e cinco) anos ou mais que comprovem não possuir meios de prover a própria manutenção nem de tê-la provida por sua família.

7 Art. 70 Para fazer jus ao benefício, a pessoa idosa e a pessoa com deficiência, além de atender aos critérios definidos na Lei no 8.742, de 1993 e nos art. $8^{\circ}$ e $9^{\circ}$ do Decreto no 6.214, de 2007, devem: I - ter nacionalidade brasileira, nata ou naturalizada, ou portuguesa; II - possuir residência no território brasileiro; III - estar inscritas no Cadastro Único, com os dados atualizados, conforme normas específicas que regulamentam o instrumento
} 
DINIZ, Silvania Aparecida; LUZ, Cícero Krupp da. Benefício de prestação continuada aos imigrantes e a decisão do recurso extraordinário 587970 do STF: direito ou calvário? Revista Eletrônica Direito e Política, Programa de Pós-Graduação Stricto Sensu em Ciência Jurídica da UNIVALI, Itajaí, v.13, n.3, $3^{\circ}$ quadrimestre de 2018. Disponível em: www.univali.br/direitoepolitica - ISSN 1980-7791

Através de uma metodologia explicativa e do ponto de vista de seus objetivos e procedimentos técnicos, bibliográfica, iremos descrever sinteticamente as diferentes formas de lidar com a concepção do direito a assistência social na forma da prestação continuada ao longo do tempo; sua principal característica como direito fundamental social e em seguida os principais fundamentos de sua legalidade (e consequente violação do direito dos refugiados no Brasil); para ao final discorrer sobre a eficácia da decisão do RE 587970 do STF no órgão administrativo da Previdência Social - INSS.

A concessão administrativa do BPC ao imigrante, sem a necessidade da intervenção do Poder Judiciário, abarca tema atual como dito acima, de extrema relevância social para o meio acadêmico e sociedade em geral, haja vista, que o dever de solidariedade social transcende o vínculo da nacionalidade, em especial ênfase nos casos que tratam da observância de direitos fundamentais humanos.

\section{O DiReito fundamental social do benefício de PRESTAÇão CONTINUADA}

Desde o advento da Constituição Federal de 1988, a assistência social passou à condição de política pública, Garcia ${ }^{8}$, diz que a assistência social na condição de política pública está equiparada ao mesmo nível da previdência social e da saúde, formando o tripé constitucional da seguridade social, ou um subsistema de proteção que incorpora a previdência social, com fito de cumprir os objetivos fundamentais elencados no artigo $3^{\circ}$ da Constituição Federal de 1988, de construir uma sociedade livre, justa e solidária; garantir o desenvolvimento nacional; erradicar a pobreza e a marginalização e reduzir as desigualdades sociais e regionais; promover o bem de todos, sem preconceitos de origem, raça, sexo, cor, idade e quaisquer outras formas de discriminação.

A partir da Declaração Universal dos Direitos do Homem (1948) foi consagrado o direito humano a proteção social em seu art. 22. Todavia, Rocha e Savaris ${ }^{9}$ adverte que a assistência social no Brasil surgiu mais recentemente, posto não existir como um direito subjetivo a proteção social, sendo prestada apenas como caridade por

8 GARCIA, Gustavo Felipe Barbosa. Curso de Direito da Seguridade Social: Previdência Social, Saúde e Assistência Social. 3a ed. Rio de Janeiro: Forense, 2017, p. 257.

9 ROCHA, Daniel Machado; SAVARIS, José Antônio. Curso de Direito Previdenciário. Curitiba: Alteridade, 2014, p.32. 
DINIZ, Silvania Aparecida; LUZ, Cícero Krupp da. Benefício de prestação continuada aos imigrantes e a decisão do recurso extraordinário 587970 do STF: direito ou calvário? Revista Eletrônica Direito e Política, Programa de Pós-Graduação Stricto Sensu em Ciência Jurídica da UNIVALI, Itajaí, v.13, n.3, $3^{\circ}$ quadrimestre de 2018. Disponível em: www.univali.br/direitoepolitica - ISSN 1980-7791

instituições religiosas, sobretudo pela Igreja Católica e as Santas Casas de Misericórdia.

E foi a Constituição Federal de $1988^{10}$, que estabeleceu o amparo social como dever do Estado, na condição de direito social de assistência aos desamparados sem qualquer contraprestação, bastando que esteja o necessitado sob o manto da pobreza. Para tanto, foi instituído o chamado Benefício de Prestação Continuada (BPC) ${ }^{11}$, benefício individual, não vitalício e intransferível, também denominado de amparo assistencial, que é a tradicional prestação pecuniária da Assistência Social.

Como corolário dessa assistência, em 1993 foi promulgado a Lei 8.742, denominada a Lei Orgânica de Assistência Social (LOAS), que passou a regulamentar o direito constitucional à assistência social, estabelecendo seus princípios informadores, suas diretrizes assistenciais e suas normas de organização ${ }^{12}$. A assistência social, nas palavras de Wladimir Novaes Martinez ${ }^{13}$ pode ser entendida como:

[...] direito do cidadão e dever do Estado, é Política de Seguridade Social não contributiva, que prevê os mínimos sociais, realizada através de um conjunto integrado de ações de iniciativa pública e da sociedade, para garantir o atendimento às necessidades básicas (art. $1^{0}$ ), ideia aduzida com o parágrafo único do art. 22: Realiza-se de forma integrada às políticas setoriais, visando ao enfrentamento da pobreza, a garantia dos mínimos sociais, ao provimento de condições para atender contingências sociais e à universalização dos direitos sociais.

10 Art. 60. São direitos sociais a educação, a saúde, a alimentação, o trabalho, a moradia, o transporte, o lazer, a segurança, a previdência social, a proteção à maternidade e à infância, a assistência aos desamparados, na forma desta Constituição.

11 Art. 203. A Assistência Social será prestada a quem dela necessitar, independentemente de contribuição à Seguridade Social e tem por objetivos - [..], V - a garantia de um salário mínimo de benefício mensal à pessoa portadora de deficiência e ao idoso que comprovem não possuir meios de prover à própria manutenção ou de tê-la provida por sua família, conforme dispuser a lei. (BRASIL, 1988, p. 72)

12 Art. $1^{0}$ - A assistência social, direito do cidadão e dever do Estado, são Política de Seguridade Social não contributiva, que provê os mínimos sociais, realizada através de um conjunto integrado de ações de iniciativa pública e da sociedade, para garantir o atendimento às necessidades básicas. (BRASIL, 1993, p.1599)

13 MARTINeZ, Wladimir Novaes. Curso de Direito Previdenciário. São Paulo: Ltr, 2010, p. 189. 
DINIZ, Silvania Aparecida; LUZ, Cícero Krupp da. Benefício de prestação continuada aos imigrantes e a decisão do recurso extraordinário 587970 do STF: direito ou calvário? Revista Eletrônica Direito e Política, Programa de Pós-Graduação Stricto Sensu em Ciência Jurídica da UNIVALI, Itajaí, v.13, n.3, $3^{\circ}$ quadrimestre de 2018. Disponível em: www.univali.br/direitoepolitica - ISSN 1980-7791

Com intuito de assistir o idoso e a pessoa com deficiência comprovadamente pobre na forma da lei, foi estabelecido na referida Lei Orgânica da Assistência Social (LOAS), o Benefício de Prestação Continuada (BPC) ${ }^{14}$. A referida lei estabelece ainda, programas e projetos de assistência social e serviços, tais como os benefícios eventuais, para situações de emergência, como a prestação de auxílio quando do nascimento ou morte em famílias de baixa renda, e casos de calamidade pública. Já os serviços têm cunho sócio assistencial, ou seja, atividades continuadas que visem à melhoria de vida da população e cujas ações devem ser voltadas para as necessidades básicas, observando os objetivos, princípios e diretrizes estabelecidos. Dentre as ações, programas e projetos, o de maior destaque é o BPC que foi regulamentado pelo Decreto n. 6.214, de 26 de setembro de $2007^{15}$, que em seu art. 7016 traz, de forma inadequada, como requisito da concessão do referido benefício a nacionalidade brasileira (nata ou naturalizada), excluindo, desse modo, todos os imigrantes do rol. Razão dessa distinção, é que abordaremos a seguir, a legitimação (violação desse direito).

\section{A LEGITIMAÇÃo E A VIOLAÇÃO dO DIREITO DE ASSISTÊNCIA SOCIAL AOS ESTRANGEIROS NO BRASIL}

A dinâmica do capitalismo neoliberal estrutura os deslocamentos de pessoas ao transformar os modos de produção e acumulação do capital e ainda criar um mercado global de capitais (mercadoria e trabalho precário), mas com controle que atenda as demandas de flexibilização e redução de custos. Por outro lado, as lutas dos imigrantes, são reivindicações concretas de mobilidade que forçam as

\footnotetext{
${ }^{14}$ Art. 20. O benefício de prestação continuada é a garantia de um salário-mínimo mensal à pessoa com deficiência e ao idoso com 65 (sessenta e cinco) anos ou mais que comprovem não possuir meios de prover a própria manutenção nem de tê-la provida por sua família. (Redação dada pela Lei no 12.435, de 2011) (Lei n. 8.742/1993).

15 O Decreto n. 6.214/2007 revogou o antigo Decreto n. 1744/1995 e sofreu algumas alterações a partir dos Decretos n. 6.564/2008 e n. 7.617/2011 e 8.805/2016.

16 Art. 70 O Benefício de Prestação Continuada é devido ao brasileiro, nato ou naturalizado, e às pessoas de nacionalidade portuguesa, em consonância com o disposto no Decreto no 7.999 , de 8 de maio de 2013, desde que comprovem, em qualquer dos casos, residência no Brasil e atendam a todos os demais critérios estabelecidos neste Regulamento. (2007, p. 16, original)
} 
DINIZ, Silvania Aparecida; LUZ, Cícero Krupp da. Benefício de prestação continuada aos imigrantes e a decisão do recurso extraordinário 587970 do STF: direito ou calvário? Revista Eletrônica Direito e Política, Programa de Pós-Graduação Stricto Sensu em Ciência Jurídica da UNIVALI, Itajaí, v.13, n.3, $3^{\circ}$ quadrimestre de 2018. Disponível em: www.univali.br/direitoepolitica - ISSN 1980-7791

fronteiras da cidadania, que nas palavras de Mezzadra ${ }^{17}$ é um terreno de luta e a migração em sentido concreto, é um exercício de liberdade.

A cidadania se põe nesta perspectiva como aquele espaço ao mesmo tempo objetivo (ou seja, institucional e soberano) e subjetivo (de movimento, de ação), em que a política encontra a cada vez, em circunstâncias historicamente determinadas, a própria instável representação de conjunto.

Ainda no campo das migrações, em recente pesquisa divulgada pelo Alto Comissariado das Nações Unidas para Refugiados - ACNUR há mais de 65 milhões de pessoas deslocadas pelo mundo, sendo a maior parte de pessoas na condição de Refugiadas, ou seja, o maior número já registrado na história ${ }^{18}$. (ACNUR, 2016).

O Estatuto dos Refugiados de $1951^{19}$ conceitua refugiado como sendo "as pessoas que se encontram fora do seu país por causa de fundado temor de perseguição por motivos de raça, religião, nacionalidade, opinião política ou participação em grupos sociais, e que não possam ou não queiram voltar para casa". Ainda com o intuito de amparar internacionalmente os refugiados, há também outros instrumentos e convenções regionais, como a Convenção da Organização de Unidade Africana (OUA) de 1969, que acresceu ao conceito de refugiado:

[...] qualquer pessoa que, devido a uma agressão, ocupação externa, dominação estrangeira ou a acontecimentos que perturbem gravemente a ordem pública numa parte ou na totalidade do seu país de origem ou do país de que tem nacionalidade, seja obrigada a deixar o lugar da residência habitual para procurar refúgio noutro lugar fora do seu país de origem ou de nacionalidade. (art. 10, p. 2)

17 MEZZADRA, Sandro. Diritto di Fuga. Migrazioni, cittadinanza, globalizzazione. Verona: Ombre Corte, 2006, p.22.

18 Somente no Brasil, o número de solicitações aumentou 2.868\% entre os anos de 2010 e 2015 , passando o país a ter 8.863 refugiados reconhecidos, sendo a maior parte advinda da Síria (ACNUR, 2016).

19 A Convenção Relativa ao Estatuto dos Refugiados de 1951 consolida a proteção aos Refugiados na legislação internacional, estabelecendo padrões básicos de tratamento aos Refugiados e cláusulas principiológicas essenciais, desde a própria definição de Refugiado até a positivação de Princípios já consagrados no direito Internacional, como o Princípio do Non-Refoulement (não-devolução), o qual possui força de jus cogens - norma imperativa a qualquer nação (ACNUR, 2016) 
DINIZ, Silvania Aparecida; LUZ, Cícero Krupp da. Benefício de prestação continuada aos imigrantes e a decisão do recurso extraordinário 587970 do STF: direito ou calvário? Revista Eletrônica Direito e Política, Programa de Pós-Graduação Stricto Sensu em Ciência Jurídica da UNIVALI, Itajaí, v.13, n.3, $3^{\circ}$ quadrimestre de 2018. Disponível em: www.univali.br/direitoepolitica - ISSN 1980-7791

Entretanto, foi a Declaração de Cartagena $(1984)^{20}$, que trouxe um conceito de Refugiados mais abrangente, definindo-o como:

[...] a pessoa que, tenham fugido dos seus países porque a sua vida, segurança ou liberdade tenham sido ameaçadas pela violência generalizada, a agressão estrangeira, os conflitos internos, a violação maciça dos direitos humanos ou outras circunstâncias que tenham perturbado gravemente a ordem pública. ( $3^{a}$ conc.)

E foi por meio do Decreto 50.215 em $1961^{21}$, que o Brasil, ratificou a Convenção de 1951, se comprometendo ao cumprimento, instituindo verdadeiro princípio de proteção pública.

Jubilut ${ }^{22}$ aduz que a partir da Lei 9.474, de 22 de julho de 1997 - Lei dos Refugiados, o Brasil passou a reconhecer o status de refugiado, estabelecendo critérios e procedimentos para a concretização da Justiça, criando inclusive, um órgão administrativo competente para tratar do tema, o Comitê Nacional para Refugiados (CONARE ${ }^{23}$ ), cuja competência dentre outras estabelecidas é a de "orientar e coordenar as ações necessárias à eficácia da proteção, assistência e apoio jurídico aos refugiados", bem como a de "declarar o reconhecimento da condição de Refugiado".

De outro lado, a nossa Carta Magna, em seu artigo 50, caput, assegura aos estrangeiros residentes no país, a inviolabilidade de seus direitos à vida, à liberdade, à igualdade, à segurança e à propriedade, tanto quanto aos brasileiros. Por sua vez, o artigo 203 dispõe que: "a assistência social será prestada a quem

\footnotetext{
20 Esse mesmo conceito foi trazido no art. $1^{\circ}$ da Lei 9.474 de 1997 , promulgada no Brasil, onde restou estabelecido que cabe a mesma Lei definir os mecanismos de implementação do Estatuto dos Refugiados de 1951 e determinar outras providências (BRASIL, 1997).

${ }^{21}$ Art. 23 os Estados Contratantes darão aos refugiados que residam regularmente no seu território o mesmo tratamento em matéria de assistência e de socorros públicos que é dado aos seus nacionais.

22 JUBILUT, Liliana Lyra. O Direito Internacional dos Refugiados: e sua Aplicação no Ordenamento Jurídico Brasileiro. São Paulo: Método, 2007, p.190.

23 O CONARE é o órgão do governo brasileiro responsável pela elaboração de políticas públicas e elegibilidade dos casos de refugiados, é formado por representantes do MJ, Ministério das Relações Exteriores (MRE), Ministério da Educação, Ministério do Trabalho (MT), Ministério da Saúde (MS), Departamento da PF, Organização não governamental ligada à temática dos refugiados (Cáritas) e o Alto Comissariado das Nações Unidas para Refugiados (ACNUR), como membro convidado, com voz, porém sem voto.
} 
DINIZ, Silvania Aparecida; LUZ, Cícero Krupp da. Benefício de prestação continuada aos imigrantes e a decisão do recurso extraordinário 587970 do STF: direito ou calvário? Revista Eletrônica Direito e Política, Programa de Pós-Graduação Stricto Sensu em Ciência Jurídica da UNIVALI, Itajaí, v.13, n.3, $3^{\circ}$ quadrimestre de 2018. Disponível em: www.univali.br/direitoepolitica - ISSN 1980-7791

dela necessitar, independentemente de contribuição social". Da mesma forma, o Estatuto do Estrangeiro (1980), em seu art. 95 preconiza que: "o estrangeiro residente no Brasil goza de todos os direitos reconhecidos aos brasileiros, nos termos da Constituição e das leis", o que, obviamente podem ser aplicados aos Refugiados, que se adequem a condição estrangeiro, embora haja algumas peculiaridades próprias diferente dos demais estrangeiros.

Partindo dos apontamentos acima que legitimam a condição de estrangeiro, e ao abordarmos a solidariedade como um dos princípios da seguridade social, afirma Santos $^{24}$ tem-se que a estrutura econômica, social e política que compele os imigrantes a tomar a decisão de imigrar é internacional. Com essa premissa, temse que o correto deveria ser tratamento igualitário a todos os residentes, não podendo ser óbice contra princípios constitucionais - direitos fundamentais, a sua regularização no país estrangeiro. Contudo, mesmo diante de normas internas e internacionais, é comum encontrar na própria legislação algumas contradições aos direitos dos estrangeiros. É o caso da assistência social, que restringe o direito aos refugiados quando estabelece que "é devido o benefício de prestação continuada ao brasileiro, naturalizado ou nato, que comprove domicílio e residência no Brasil e atenda a todos os demais critérios estabelecidos neste regulamento" (art. 70). Em contrapartida, a própria Constituição Federal prevê a prestação do benefício a quem dela necessitar.

Com essa imposição legal, o imigrante está condicionado a naturalização como requisito primordial para a percepção do Benefício de Prestação Continuada. Nessa linha de raciocínio temos ainda o próprio art. $1^{\circ}$ da referida LOAS, que também se contrapõe a norma constitucional, quando limita a assistência social como direito do cidadão. Aqui a legislação infraconstitucional, estaria limitando a previsão constitucional da assistência social para quem dela necessitar, uma vez que excluem de seu rol os imigrantes.

24 SANTOS, Marisa Ferreira dos. Direito Previdenciário Esquematizado. 3. ed. São Paulo: Saraiva, 2013, p. 27. 
DINIZ, Silvania Aparecida; LUZ, Cícero Krupp da. Benefício de prestação continuada aos imigrantes e a decisão do recurso extraordinário 587970 do STF: direito ou calvário? Revista Eletrônica Direito e Política, Programa de Pós-Graduação Stricto Sensu em Ciência Jurídica da UNIVALI, Itajaí, v.13, n.3, $3^{\circ}$ quadrimestre de 2018. Disponível em: www.univali.br/direitoepolitica - ISSN 1980-7791

Castro e Lazzari25 afirmam que um dos basilares princípios da Seguridade Social a universalidade da cobertura e do atendimento se traduz que a proteção social deve alcançar todos os eventos cuja reparação seja premente, a fim de manter a subsistência de quem dela necessite, não fazendo, portanto, a norma constitucional qualquer distinção entre nacionais e estrangeiros.

Comungando com essa esteira de que a exclusão de um direito fundamental humano, mostra-se incoerente com o nosso ordenamento jurídico, o Ministério do Desenvolvimento Social e Combate a Fome ${ }^{26}$, através do Ofício Circular Conjunto n. 02/2004 - SENARC/MDS e SNAS/MDS DE 11/02/201427, descreveu que o Benefício de Prestação Continuada é direito único dos cidadãos brasileiros (art. 70 do Decreto 6.214/200728); o Instituto de Seguro Social (INSS), por meio da Resolução INSS/PRES n. 435 de 18/03/199729, e ainda, Portaria Conjunta MDSA/INSS no 1 , de 03 de janeiro de $2017^{30}$ - dou de 04/01/2017, descrevem a nacionalidade como condição de recebimento do Benefício.

Diante desse cenário incongruente, essa discussão tornou-se palco de indignação no tratamento dos refugiados provocando em 2010, o Ministério Público Federal

\footnotetext{
25 CASTRO, Carlos Alberto Pereira de; LAZZARI, João Batista. Manual de Direito Previdenciário. $16^{\mathrm{a}}$ ed. Rio de Janeiro: Forense, 2014, p. 70.

26 É quem autoriza a inscrição de estrangeiros no Cadastro Único e acesso ao Programa do Bolsa Família.

27 Contudo, estão vedados aos estrangeiros que residem legalmente no Brasil, os direitos expressamente reservados aos cidadãos brasileiros. No tocante ao acesso aos serviços sociais, o Benefício de Prestação Continuada da Assistência Social - BPC trata-se de direito exclusivo de brasileiros, conforme definição do artigo 70 do Decreto 6.214/97. Segundo o regulamento deste benefício, o BPC é devido ao brasileiro nato ou naturalizado, que comprove domicílio e residência no Brasil e atenda a todos os demais critérios legais.
}

28 Art. 70 O Benefício de Prestação Continuada é devido ao brasileiro, nato ou naturalizado, e às pessoas de nacionalidade portuguesa, em consonância com o disposto no Decreto no 7.999, de 8 de maio de 2013, desde que comprovem, em qualquer dos casos, residência no Brasil e atendam a todos os demais critérios estabelecidos neste Regulamento

29 4. São também beneficiários os estrangeiros idosos e portadores de deficiência, naturalizados e domiciliados no Brasil, desde que não amparados pelo sistema previdenciário do país de origem, bem como os indígenas.

30 Art. 70 Para fazer jus ao benefício, a pessoa idosa e a pessoa com deficiência, além de atender aos critérios definidos na Lei no 8.742, de 1993 e nos art. $8^{\circ}$ e $9^{\circ}$ do Decreto no 6.214, de 2007, devem: I - ter nacionalidade brasileira, nata ou naturalizada, ou portuguesa;

II - Possuir residência no território brasileiro; III - estar inscritas no Cadastro Único, com os dados atualizados, conforme normas específicas que regulamentam o instrumento. 
DINIZ, Silvania Aparecida; LUZ, Cícero Krupp da. Benefício de prestação continuada aos imigrantes e a decisão do recurso extraordinário 587970 do STF: direito ou calvário? Revista Eletrônica Direito e Política, Programa de Pós-Graduação Stricto Sensu em Ciência Jurídica da UNIVALI, Itajaí, v.13, n.3, $3^{\circ}$ quadrimestre de 2018. Disponível em: www.univali.br/direitoepolitica - ISSN 1980-7791

do Estado de São Paulo a propor Ação Civil Pública ${ }^{31}$ para a concessão do BPC a três palestinos refugiados no Brasil. Entretanto, foi a ação extinta sem resolução do mérito, ante o entendimento de ilegitimidade do Ministério Público para defesa de interesses individuais em discussão. Outro ${ }^{32}$ caso amplamente divulgado tratase de um cidadão Palestino que perdeu toda família num atentado no Iraque e passou a viver em campos de refugiados. Na época, com mais de 70 anos, ele veio morar no Brasil por meio do Programa de Reassentamento Solidário do Alto Comissariado das Nações Unidas para Refugiados (ACNUR), de onde recebia auxílio-moradia no valor de $\mathrm{R} \$ 500,00$, mas, não era suficiente para cobrir suas despesas de moradia e medicamentos. O palestino teve negado o Benefício de Prestação Continuada pelo INSS e por meio da Defensoria Pública da União foi-Ihe requerida a prestação do Benefício de Prestação Continuada, visto que ele não possuía o mínimo necessário para o seu provento e manutenção. A autarquia previdenciária alegou que não existe nenhum tipo de obrigação do Brasil quanto a prestação do benefício ao Refugiado, por conta da ausência de um acordo de reciprocidade entre o Brasil e a Palestina para a prestação assistencial, tanto de palestinos no Brasil, como de brasileiros na Palestina. A sentença proferida pelo $3^{0}$ Juízo Federal de Canoas/RS possibilitou a concessão ao Palestino o Benefício de Prestação Continuada desde a data da solicitação administrativa. No caso relatado, tanto quanto outros, o caminho seguido encontra-se longe do ideal, isso porque, em regra, o Instituto Nacional de Seguridade Social deveria conceder o benefício uma vez comprovados os requisitos da lei.

Em contrapartida, o jornal BBC 33 , divulgou em matéria circulada em 14/11/2015, centenas de Sírios que no Brasil encontraram amparo assistencial do Programa de

31 BRASIL - Ministério Público Federal. Ação civil pública no 0023528-28.2010.4.03.6100(2010). Disponível em: <www.prsp.mpf.gov.br/prdc/sala-de-imprensa/pdfs-dasnoticias/ACP_Palestinos.pdf> Acesso em: 07 jan. 2018

32 BRASIL. Tribunal Regional Federal da $4^{a}$ Região - Seção Judiciária de Canoas/RS. (2015) Disponível em: <https://www2.jfrs.jus.br/justica-federal-em-canoas-rs-concede-beneficioassistencial-a-refugiado-palestino/> Acesso em: 12. Mar.2018.

33 BANDEIRA, Luiza. Sem programa específico para refugiados, Brasil põe centenas de sírios no Bolsa Família. (2015). Disponível em: http://www.bbc.com/portuguese/noticias/2015/10/151013_bolsa_familia_sirios_lab> Acesso em: 12. Mar.2018. 
DINIZ, Silvania Aparecida; LUZ, Cícero Krupp da. Benefício de prestação continuada aos imigrantes e a decisão do recurso extraordinário 587970 do STF: direito ou calvário? Revista Eletrônica Direito e Política, Programa de Pós-Graduação Stricto Sensu em Ciência Jurídica da UNIVALI, Itajaí, v.13, n.3, $3^{\circ}$ quadrimestre de 2018. Disponível em: www.univali.br/direitoepolitica - ISSN 1980-7791

transferência de renda, o Bolsa Família. Contudo, essa assistência social na condição de transferência de renda encontra-se em desacordo com o verdadeiro sentido da assistência social cravada no art. 203 da Constituição Federal. A primeira, o denominado programa "o bolsa família" tem caráter assistencialista, já o BPC, se destaca pelo direito fundamental da dignidade da pessoa humana.

\section{CONSIDERAÇÕES SOBRE O RE 587970/STF}

Todas essas incongruências na assistência social estampadas e o excesso de processos judiciais para obtenção do BPC aos imigrantes, refugiados irregulares ou não, acabou por provocar o Supremo Tribunal Federal a lançar a decisão no Recurso Extraordinário (RE) $587970^{34}$, de repercussão geral.

O referido processo teve sua origem em 2005, quando a autora uma imigrante italiana, solicitou ao Instituto Nacional de Seguridade Social (INSS) a concessão do BPC. Mesmo preenchendo todos os requisitos definidos na legislação, o INSS negou seu pedido, alegando que o benefício se restringe a brasileiros. A imigrante italiana ingressou com ação previdenciária onde a decisão de primeira instância concedeu o referido benefício, sustentando que a mesma cumpria todos os requisitos legais e, por isso, condenou o INSS a fazê-lo, sob pena de multa diária. Em segunda instância, alegou o INSS, que a italiana não se naturalizou brasileira, não fazendo jus ao BPC. No entanto, foi negado provimento ao recurso do INSS, por entender que o artigo 203-A da Constituição Federal de 1988 estende a assistência social "a quem dela necessitar". Razão disso, o INSS, promoveu recurso extraordinário alegando desta vez, violação do o artigo 203-A, V, da Constituição Federal ao argumento de que a lei regulamentadora, qual seja a Lei federal 8.742/1993 (LOAS), condiciona a concessão do benefício aos "cidadãos", excluindo estrangeiros não naturalizados. Consequência disso, esse tema foi julgado em 22/09/2017 pelo Supremo Tribunal Federal, em sede de Repercussão

\footnotetext{
34 BRASÍLIA. SUPREMO TRIBUNAL FEDERAL. Concessão de benefício assistencial a estrangeiros residentes no Brasil. Disponível em: http://stf.jus.br/portal/jurisprudenciarepercussao/verAndamentoProcesso.asp?incidente $=2621386 \&$ numeroProcesso $=587970 \&$ classeProcesso $=$ RE\&numeroTema=173 $>$. Acesso em: 06 jan. 2018.
} 
DINIZ, Silvania Aparecida; LUZ, Cícero Krupp da. Benefício de prestação continuada aos imigrantes e a decisão do recurso extraordinário 587970 do STF: direito ou calvário? Revista Eletrônica Direito e Política, Programa de Pós-Graduação Stricto Sensu em Ciência Jurídica da UNIVALI, Itajaí, v.13, n.3, $3^{\circ}$ quadrimestre de 2018. Disponível em: www.univali.br/direitoepolitica - ISSN 1980-7791

Geral no Recurso Extraordinário, passando-se a permitir a aplicação do Benefício de Prestação Continuada ao estrangeiro.

Diante desse quadro de legitimação (violação) e da necessidade de pronunciamento do poder judiciário para a concessão do BPC ao imigrante, tornase de extrema relevância descrever a decisão adotada por nossa Corte maior. Entretanto, inicialmente, cumpre destacar a posição defendida pela administração pública, tanto administrativamente, quanto judicialmente. Nesse sentido, sustentou a autarquia previdenciária, através de sua procuradoria que o art. 10, da Lei no 8.742/93, que reconhece a assistência social, é direito do cidadão. $E$, do ponto de vista do direito constitucional, cidadão é aquele nacional que está em gozo dos seus direitos políticos, vale dizer, que possua alistamento eleitoral, conforme já foi decidido na ADI no 3.593 de relatoria do Ministro Gilmar Mendes.

A Procuradoria Geral da República no caso sob análise cuja repercussão geral foi reconhecida pelo STF, manifestou-se com a fundamentação ora sintetizada de que o Brasil e Itália embora possuam acordo bilateral relacionado à Previdência Social, mas em relação à assistência social, não há nenhum registro. Que ao estabelecer os beneficiários do BPC, o enumera em um rol, respeitando os critérios de permanência no país e que a assistência social é matéria soberana de cada Estado e está intimamente ligada a reserva do possível e que no Estado brasileiro, à mingua de uma previsão legal, não há como estender o benefício aos estrangeiros, ainda que residentes no Brasil, pois essa foi a escolha do nosso legislador. Apreciado o recurso por nossa Corte maior, proferiu decisão publicada no DJU do dia 22/09/2017, com a seguinte ementa:

ASSISTÊNCIA SOCIAL - ESTRANGEIROS RESIDENTES NO PAÍS - ARTIGO 203, INCISO V, DA CONSTITUIÇÃO FEDERAL - ALCANCE. A assistência social prevista no artigo 203, inciso $V$, da Constituição Federal beneficia brasileiros natos, naturalizados e estrangeiros residentes no País, atendidos os requisitos constitucionais e legais.

Para o proposto no presente artigo, ou seja, a análise crítica que se pretende realizar adiante, necessário se faz a transcrição de trechos dos fundamentos da decisão, ora postos seguidos de comentários. No fundamento do voto do relator, tem-se: 
DINIZ, Silvania Aparecida; LUZ, Cícero Krupp da. Benefício de prestação continuada aos imigrantes e a decisão do recurso extraordinário 587970 do STF: direito ou calvário? Revista Eletrônica Direito e Política, Programa de Pós-Graduação Stricto Sensu em Ciência Jurídica da UNIVALI, Itajaí, v.13, n.3, $3^{\circ}$ quadrimestre de 2018. Disponível em: www.univali.br/direitoepolitica - ISSN 1980-7791

[...] A questão mostra-se das mais relevantes. Está em jogo definir se a nacionalidade brasileira deve ser considerada requisito para a concessão do benefício assistencial previsto no artigo 203, inciso V, da Carta da República.

[...] A Assembleia Nacional Constituinte de 1987/1988, imbuída de espírito inclusivo e fraternal, fez constar o benefício assistencial previsto no artigo 203, inciso V, da Lei Básica da República. Consubstancia especialização dos princípios maiores da solidariedade e da erradicação da pobreza, versados no artigo 30 , incisos I e III, nela contido. Concretiza a assistência aos desamparados, estampada no artigo 60, cabeça, do Diploma Maior. Daí ostentar a natureza de direito fundamental.

De início, o respeitável julgado destaca a importância da questão posta em foco, e para seu deslinde e visando a coerência de entendimentos tomou por base a discussão afeta à matéria já travada naquele Tribunal quando do julgamento do RE no 567.985/MT ${ }^{35}$, no qual se examinou a constitucionalidade do critério estabelecido pela Lei no $8.742 / 1993^{36}$ para aferição da condição de hipossuficiência. Lançou o relator argumentos veiculados no voto proferido naquela oportunidade, destacando a assistência social como direito fundamental, a ser concedido por meio do BPC, o de maior destaque na legislação, para garantir a assistência aos desamparados. Prosseguindo, assenta:

[...] mesmo considerada a interpretação feita pelos outros Poderes da República, o intérprete último da Constituição é o Supremo. Cumpre ao Tribunal sopesar, com base nos preceitos do Diploma Maior, as concretizações efetuadas pelo legislador. Nessa relação de tensão entre a normatividade constitucional, a infraconstitucional e a facticidade inerente ao fenômeno jurídico, incumbe-lhe dar prioridade à tarefa de resguardar a integridade da Lei Fundamental. Sem esse controle, prevaleceria a interpretação do texto constitucional conforme à lei, a demonstrar abandono da rigidez própria àquela. Como, então, deve ser percebida a cláusula

35 BRASÍLIA. SUPREMO TRIBUNAL FEDERAL. Benefício assistencial de prestação continuada ao idoso e ao deficiente. Art. 203, V, da Constituição. Disponível em: <http://redir.stf.jus.br/paginadorpub/paginador.jsp?docTP=TP\&docID=4614447> Acesso em: 07 abr. 2018

36 O requisito financeiro estabelecido pela lei teve sua constitucionalidade contestada, ao fundamento de que permitiria que situações de patente miserabilidade social fossem consideradas fora do alcance do benefício assistencial previsto constitucionalmente. 
DINIZ, Silvania Aparecida; LUZ, Cícero Krupp da. Benefício de prestação continuada aos imigrantes e a decisão do recurso extraordinário 587970 do STF: direito ou calvário? Revista Eletrônica Direito e Política, Programa de Pós-Graduação Stricto Sensu em Ciência Jurídica da UNIVALI, Itajaí, v.13, n.3, $3^{\circ}$ quadrimestre de 2018. Disponível em: www.univali.br/direitoepolitica - ISSN 1980-7791

constitucional "a assistência social será prestada a quem dela necessitar"? O objetivo do constituinte foi único: conferir proteção àqueles incapazes de garantir a subsistência. Os preceitos envolvidos, como já asseverado, são os relativos à dignidade humana, à solidariedade social, à erradicação da pobreza e à assistência aos desamparados. Esses elementos fornecem base para interpretação adequada do benefício assistencial estampado no Documento Básico.

Nesse contexto, a decisão destaca que cabe ao Supremo Tribunal Federal, como guardião da Constituição, interpretar e resguardar a integridade da lei fundamental, exercendo controle, pois a lei tem papel crucial na definição dos limites necessários e é essencial à manutenção da normatividade constitucional. E que no contexto dos preceitos envolvidos da dignidade humana, a solidariedade, erradicação da pobreza e assistência aos desamparados, no caso sob judice, outra leitura não deve ser dada ao texto constitucional que não seja a de garantir a subsistência aos desamparados, pois este é o conceito formal do BPC.

Após a análise das variantes constitucionais e legais, passou-se à discussão do princípio da reciprocidade, onde restou pronunciado:

[...] descabe o argumento de pertinência do princípio da reciprocidade, ou seja, arguir que o benefício somente poderia ser concedido a estrangeiro originário de País com o qual o Brasil firmou acordo internacional e que preveja a cobertura da assistência social a brasileiro que esteja em seu território. Apesar de a reciprocidade permear a Carta, não é regra absoluta quanto ao tratamento dos não nacionais.

Aqui a decisão proclamou que apesar do dever de reciprocidade previsto na Constituição Federal, não é regra maior no tratamento dos não nacionais. Nesse contexto a decisão ensejou que a aplicação do princípio de reciprocidade pode ter seus efeitos limitados quando o objeto de requerimento possa de alguma forma contrariar o ordenamento jurídico do país que está sendo requerido, desconsiderando sua soberania, sua segurança jurídica, a ordem pública ou outros interesses fundamentais do Estado, motivo pelo qual não se torna pertinente a aplicação do referido princípio como regra geral.

Passando a análise dos tratados internacionais, o RE assentou: 
DINIZ, Silvania Aparecida; LUZ, Cícero Krupp da. Benefício de prestação continuada aos imigrantes e a decisão do recurso extraordinário 587970 do STF: direito ou calvário? Revista Eletrônica Direito e Política, Programa de Pós-Graduação Stricto Sensu em Ciência Jurídica da UNIVALI, Itajaí, v.13, n.3, $3^{\circ}$ quadrimestre de 2018. Disponível em: www.univali.br/direitoepolitica - ISSN 1980-7791

[...] E devemos lembrar que o Brasil é signatário de tratados internacionais, pelos quais se repudia qualquer discriminação fundada na origem nacional e se exige a adoção de medidas que progressivamente e assegurem a efetividade de direitos econômicos e sociais. Por exemplo, cite-se a Declaração Universal dos Direitos Humanos e a Convenção Americana de Direitos Humanos (grifos aditados): Declaração Universal dos Direitos do Homem 1948, Artigo 2. 1. Todo ser humano tem capacidade para gozar os direitos e as liberdades estabelecidos nesta Declaração, sem distinção de qualquer espécie, seja de raça, cor, sexo, idioma, religião, opinião política ou de outra natureza, origem nacional ou social, riqueza, nascimento, ou qualquer outra condição. (...) Artigo 22. Todo ser humano, como membro da sociedade, tem direito à segurança social e à realização, pelo esforço nacional, pela cooperação internacional e de acordo com a organização e recursos de cada Estado, dos direitos econômicos, sociais e culturais indispensáveis à sua dignidade e ao livre desenvolvimento da sua personalidade. Convenção Americana de Direitos Humanos, Artigo 1. Obrigação de respeitar direitos. Os Estados Partes nesta Convenção comprometem-se a respeitar os direitos e liberdades nela reconhecidos e a garantir seu livre e pleno exercício a toda pessoa que esteja sujeita à sua jurisdição, sem discriminação alguma por motivo de raça, cor, sexo, idioma, religião, opiniões políticas ou de qualquer outra natureza, origem nacional ou social, posição econômica, nascimento ou qualquer outra condição social.

O destaque nesse trecho deu-se a participação do Brasil em diversos acordos internacionais, onde estabeleceu-se como norma imperativa, a obrigação de respeito mútuo aos direitos e liberdades neles inseridos e reconhecidos. Isso porque, os tratados citados vedam qualquer forma de diferenciação (raça, cor, sexo etc.), que tem o propósito de anular ou prejudicar o reconhecimento, o gozo ou o exercício em pé de igualdade de direitos humanos e liberdades fundamentais nos campos econômico, social, cultural ou qualquer campo da vida pública. Prosseguindo e individualizando os tratados e convenções, destaca a decisão:

[...] além disso, o Brasil é signatário e incorporou no seu ordenamento jurídico nos termos do $\S 30$ do artigo 50, a Convenção de Nova Iorque, que ingressou no Brasil com status constitucional - diga-se de passagem, por enquanto, a primeira e única convenção que se utilizou do novo procedimento do $\S 30$ do artigo 50, trazido pela Emenda 45 , em relação às pessoas com deficiência. E a Convenção de 
DINIZ, Silvania Aparecida; LUZ, Cícero Krupp da. Benefício de prestação continuada aos imigrantes e a decisão do recurso extraordinário 587970 do STF: direito ou calvário? Revista Eletrônica Direito e Política, Programa de Pós-Graduação Stricto Sensu em Ciência Jurídica da UNIVALI, Itajaí, v.13, n.3, $3^{\circ}$ quadrimestre de 2018. Disponível em: www.univali.br/direitoepolitica - ISSN 1980-7791

Nova Iorque, incorporada após a aprovação, em dois turnos, em cada uma das Casas Legislativas, por três quintos, incorporada ao nosso ordenamento jurídico pelo Decreto presidencial no 6.949, de 25 de agosto de 2009, expressamente proibiria qualquer forma de discriminação em relação às pessoas com deficiência.

[...] Mas vai mais além, depois, no artigo 28, item 2, alíneas "b" e "c", que obriga os Estados-partes - e o Brasil é um deles: "b) Assegurar o acesso de pessoas com deficiência, particularmente mulheres, crianças e idosos com deficiência, a programas de proteção social e de redução da pobreza; c) Assegurar o acesso de pessoas com deficiência e suas famílias em situação de pobreza à assistência do Estado em relação a seus gastos ocasionados pela deficiência [...] a incorporação da Convenção de Nova Iorque, em 2009, com status constitucional, reforçou essa impossibilidade de discriminação na assistência social tão somente pelo fato da nacionalidade.

Dando ênfase à Convenção de Nova Iorque, que tem status constitucional, a decisão nesse sentido, demonstrou que a referida Convenção, trouxe além das garantias à liberdade, direitos sociais específicos ao portador de deficiência, quando atribuiu ao Estado o dever de proteção social e redução da pobreza em relação aos gatos ocasionados pela deficiência, bem como, prestar a assistência social, através do BPC. E o fazendo assim, a Convenção não distinguiu nacionais de estrangeiros, referindo-se apenas à pessoa com deficiência, não podendo dar outro entendimento discriminatório ao que disposto restou. Ainda nesse viés dos Tratados internacionais, a decisão assentou:

[...] um ato de direito internacional, como tratado ou garantia de reciprocidade, não teria, em regra, a aptidão de restringir o alcance determinado pela Constituição (exceto na hipótese de internalização de tratados na forma do art. 50, § $30, \mathrm{CF}$ ). $\mathrm{E}$, como visto, os tratados internacionais ratificados pelo Brasil não indicam qualquer restrição ao alcance da assistência social, pelo contrário, reclamam a extensão dessa cobertura assistencial a todas as pessoas, [...] excluída qualquer discriminação fundada na origem ou nacionalidade.

Como estampado, perseguiu a discussão sobre a aplicação do princípio da reciprocidade, onde destacou que o tratado internacional não tem o condão de restringir o alcance da norma constitucional, isso porque, somente os tratados incorporados com equivalência a emenda constitucional tem força normativa 
DINIZ, Silvania Aparecida; LUZ, Cícero Krupp da. Benefício de prestação continuada aos imigrantes e a decisão do recurso extraordinário 587970 do STF: direito ou calvário? Revista Eletrônica Direito e Política, Programa de Pós-Graduação Stricto Sensu em Ciência Jurídica da UNIVALI, Itajaí, v.13, n.3, $3^{\circ}$ quadrimestre de 2018. Disponível em: www.univali.br/direitoepolitica - ISSN 1980-7791

superior. Sendo assim, os tratados internacionais de seguridade social não vedam a prestação de assistência social na forma do BPC aos estrangeiros, utilizado o fator nacionalidade ou territorialidade como óbice, ensejando o contrário, ou seja, têm o dever de solidariedade social que transcende o vínculo da nacionalidade, com especial ênfase nos casos que tratam da observância de direitos fundamentais.

Superada a exposição acima através de uma curta síntese, observa-se que os fundamentos opostos na decisão, ensejam uma análise crítica a partir de uma leitura sistêmica, haja vista, que os conteúdos constitucionais não condicionam a concessão do benefício a um fato, seja ele nacionalidade ou até mesmo cidadania, o que permite pensar que os sistemas devem agir com maior eficácia e de acordo com os processos do mundo natural e econômico.

\section{DIREITO OU CALVÁRIO?}

A despeito da posição da Procuradoria da União, a questão levada a efeito, no RE 587970 e publicada em 22/09/2017, estabeleceu que na "relação de tensão entre a normatividade constitucional, a infraconstitucional e a facticidade inerente ao fenômeno jurídico, incumbe dar prioridade à tarefa de resguardar a integridade da Lei Fundamental". Assim, sendo ao intérprete último da Constituição - o Supremo cumpre sopesar, com base nos preceitos do diploma maior, as concretizações efetuadas pelo legislador; e como tal, não quis o legislador ao conceder o benefício de prestação continuada (BPC) a quem dele necessitar, excluir os de nacionalidades diferentes, pelo simples fato da ausência de reciprocidade nos tratados internacionais, ou especificidade na norma constitucional (interna).

O fim precípuo da decisão proferida foi no sentido de que conteúdos constitucionais sejam interpretados à luz da realidade concreta da sociedade, dos avanços culturais e dos choques que inevitavelmente ocorrem no exercício dos direitos fundamentais previstos, apenas de modo abstrato, no texto maior. A lei tem papel crucial na definição dos limites necessários. Essa é a atividade essencial à manutenção da normatividade constitucional, que, para ter efetividade, precisa estar alicerçada no espírito, na cultura e nas vocações de um povo. E foi nesse sentido que o contexto justificador (fundamentos) da decisão se assentou. Embora a decisão tenha esse raciocínio maior, a realidade prática da Advocacia 
DINIZ, Silvania Aparecida; LUZ, Cícero Krupp da. Benefício de prestação continuada aos imigrantes e a decisão do recurso extraordinário 587970 do STF: direito ou calvário? Revista Eletrônica Direito e Política, Programa de Pós-Graduação Stricto Sensu em Ciência Jurídica da UNIVALI, Itajaí, v.13, n.3, $3^{\circ}$ quadrimestre de 2018. Disponível em: www.univali.br/direitoepolitica - ISSN 1980-7791

Previdenciária, demonstra que essa efetividade do direito, ainda está a passo distante da realidade de um povo - os estrangeiros. Ao contrário, essa inefetividade do direito ocorre, em primeiro momento, no próprio procedimento administrativo de requerimento do BPC, perante o órgão gestor, o INSS (Instituto Nacional de Seguro Social) e persegue na atuação judicial de sua procuradoria.

Fato é que ao longo de quase cinco décadas, a comunidade internacional não atribui o devido destaque ao direito humano à seguridade social. A justificativa comum nesse cenário se dá pela ineficiência dos sistemas jurídicos em tratar o fenômeno da pobreza extrema, invocando o princípio da proteção progressiva, como corolário daquele mito segundo o qual o crescimento econômico e aumento de renda tendem a beneficiar naturalmente os setores mais pobres, de modo que a amplitude e qualidade da proteção social aumentariam automaticamente.

Nesse contexto de pobreza extrema, no Brasil, a única proteção social oferecida se dá através do programa "Bolsa Família" 37 que tem como finalidade transferir renda (dinheiro), às famílias em situação de extrema pobreza, de modo que consigam superar a situação de vulnerabilidade e pobreza. O referido programa beneficia cerca de 29.638 estrangeiros inscritos, incluindo aqueles estrangeiros que pediram refúgio no Brasil. Segundo dados divulgados pelo $\operatorname{CONARE}^{38}$ no relatório "Refúgio em Números"39, No total, 33.866 pessoas solicitaram o reconhecimento da condição de refugiado no Brasil em 2017. Os venezuelanos representam mais da metade dos pedidos realizados, com 17.865 solicitações. $\mathrm{Na}$ sequência estão os cubanos (2.373), os haitianos (2.362) e os angolanos (2.036). Os estados com mais pedidos de refúgio são Roraima (15.955), São Paulo (9.591) e Amazonas (2.864), segundo dados da Polícia Federal.

\footnotetext{
37 Lei. 10.836 de 9 de janeiro de 2004, cria o bolsa família e dá outras providências.

38 Criado pela Lei no 9.474/1997 com o objetivo de reconhecer e tomar decisões sobre a condição de refugiado no Brasil, além de promover a integração local dessa população, o Comitê Nacional para os Refugiados (CONARE) é um órgão multiministerial do qual participam o governo, a sociedade civil e a ONU, por meio do ACNUR.

39 CONARE - DADOS SOBRE REFUGIO NO BRASIL - Disponível em: $<$ http://www.acnur.org/portugues/dados-sobre-refugio/dados-sobre-refugio-no-brasil/>. Acesso em: 08 abr 2018.
} 
DINIZ, Silvania Aparecida; LUZ, Cícero Krupp da. Benefício de prestação continuada aos imigrantes e a decisão do recurso extraordinário 587970 do STF: direito ou calvário? Revista Eletrônica Direito e Política, Programa de Pós-Graduação Stricto Sensu em Ciência Jurídica da UNIVALI, Itajaí, v.13, n.3, $3^{\circ}$ quadrimestre de 2018. Disponível em: www.univali.br/direitoepolitica - ISSN 1980-7791

Para a afirmação acima, fora realizado pesquisa em todos os sites dos órgãos protetores e defensores dos direitos dos refugiados, tais quais, da Previdência Social, do Ministério do Combate à Fome, etc., ACNUR, CONARE, a fim de se verificar se haveria informação ou possibilidade do requerimento do Benefício de Prestação Continuada (BPC) pelo imigrante/refugiado. Tratando-se especificamente do BPC, verificamos que em nenhum deles há qualquer informação nesse sentido. Perante a Previdência Social (INSS), o cidadão tem a opção de requerer através de vários $\operatorname{sites}^{40}$ o benefício que tem interesse. Contudo, ao acessar o site meu INSS, de plano, o usuário deve apresentar login e senha. Para ter acesso ao cadastro de login e senha, o cidadão deverá prestar informações no site, sem opção de erro ou correção, ou com a opção de comparecer pessoalmente a uma agência do INSS ou se fazer representar por procurador imbuído de procuração, efetuar o cadastramento do código de acesso, para posteriormente cadastrar seu login e senha, ou se preferir utilizar o fale previdência através da central 135, que determinará que o cidadão compareça pessoalmente a uma agência do INSS ou acesso ao site.

Acessando o portal da previdência social, ao invés do meu INSS (duas opções de acesso), ele não encontrará a opção de requerimento de benefício assistencial ao imigrante, somente a opção benefício assistencial ao portador de deficiência e ao idoso. Sendo o imigrante (idoso ou deficiente) escolhendo uma dessas opções, deverá preencher a solicitação que inicialmente requer o número do CPF ou NIS ${ }^{41}$. Se ele for beneficiário de algum programa social concedido pelo Brasil, a exemplo o "bolsa família", ele terá o número do NIS, se ainda não tiver nem o CPF ou NIS, será necessário comparecer perante o CRAS (Centro de Referência de Assistência Social) mais próximo da sua residência para se cadastrar em um programa assistencial do governo federal e receber orientações sobre o cadastro de NIS e

\footnotetext{
40 A pesquisa e requerimento de benefícios previdenciários poderão ser realizadas nos seguintes enderecos eletrônicos: <https://meu.inss.gov.br/central/index.html\#/agenda; http://www.previdencia.gov.br/> ; <https://www.inss.gov.br/>; etc.,

41 NIS - significa Número de Identificação Social. Todo o cidadão com cadastro na previdência social, no Ministério do Trabalho, ou em benefícios sociais possui esse número que pode ser encontrado no cartão cidadão, carteira de trabalho (CTPS) ou cartão do bolsa família responsável pela inscrição do vínculo empregatício com a Previdência Social e entre outros benefícios sociais vinculados a Caixa Econômica Federal. Também identificado como NIT (Número de Inscrição do Trabalhador) que nada mais é do que o número do PIS (Programa de Integração Social)
} 
DINIZ, Silvania Aparecida; LUZ, Cícero Krupp da. Benefício de prestação continuada aos imigrantes e a decisão do recurso extraordinário 587970 do STF: direito ou calvário? Revista Eletrônica Direito e Política, Programa de Pós-Graduação Stricto Sensu em Ciência Jurídica da UNIVALI, Itajaí, v.13, n.3, $3^{\circ}$ quadrimestre de 2018. Disponível em: www.univali.br/direitoepolitica - ISSN 1980-7791

CPF e após, preencher o formulário de requerimento seja on line ou presencial do referido benefício. Admitindo-se a hipótese de o estrangeiro já possuir seu número de inscrição - NIS, ao requerer o benefício deverá apresentar toda a documentação pertinente e disposta na legislação (documento de identidade, carteira de trabalho, $\mathrm{CPF}$, NIS, comprovante de endereço, etc.). Se on line, deverá efetuar o envio através de arquivo anexo ao requerimento, na nova modalidade do INSS digital. Feito isso, será determinado um estudo social pela equipe de perícia psicossocial do INSS. Depois de realizado o estudo social, o INSS se pronunciará sobre a concessão ou não do referido benefício.

Realizado todos esses passos pelo imigrante e atendidos os requisitos legais, e ainda, mesmo diante da decisão do STF acima referenciada, a negativa é certeira, pois permanece o órgão administrativo obedecendo a seu comando interno disposto na portaria conjunta MDSA/INSS No 1 , de 03 de janeiro de $2017^{42}$, que tem como base a Lei no 8.742, de 1993 e o Decreto no 6.214, de 2007, que estabelecem os critérios de nacionalidade e a condição de cidadão, para a concessão do BPC. Não diferentemente, tem sido o comportamento de sua procuradoria. Recentes julgados dos Tribunais Federais Regionais, demonstram a necessidade da intervenção jurisdicional, para proclamar decisão já assentada e pacificada pelo Supremo Tribunal Federal ${ }^{43}$. Á exemplo trazemos:

[...] A autarquia alega, em suas razões recursais, que 0 estrangeiro estaria obstado à condição de beneficiário do BPC desde o primeiro artigo da Lei de Assistência Social, pela menção ao "cidadão". Ademais, postula que o Decreto $6546 / 2008$ dispunha em seu artigo quarto que os beneficiários deveriam ser apenas brasileiros natos e naturalizados. Ainda, argui que a exclusão do estrangeiro do rol de beneficiários é dotada de razoabilidade administrativa baseada na reserva do possível. O Supremo Tribunal Federal,

\footnotetext{
42 Art. 70 Para fazer jus ao benefício, a pessoa idosa e a pessoa com deficiência, além de atender aos critérios definidos na Lei no 8.742, de 1993 e nos art. $8^{\circ}$ e 90 do Decreto no 6.214, de 2007, devem: I - ter nacionalidade brasileira, nata ou naturalizada, ou portuguesa; II - possuir residência no território brasileiro; III - estar inscritas no Cadastro Único, com os dados atualizados, conforme normas específicas que regulamentam o instrumento

43 BRASIL. Tribunal Regional Federal da $4^{a}$ Região. Jurisprudência no 501391572.2016.4.04.7000/PR. Relator: Juiz Federal VICENTE DE PAULA ATAÍDE JUNIOR. Curitiba, PR, 15 de fevereiro de 2018. Diário Eletrônico da Justiça Federal. Curitiba, 15 fev. 2018. Disponível em: < https://jurisprudencia.trf4.jus.br/pesquisa/inteiro_teor.php?orgao=4\&documento=9428798\&termo sPesquisados=IGJwYyBlc3RyYW5nZWlybyA $>$. Acesso em: 13. mar. 2018
} 
DINIZ, Silvania Aparecida; LUZ, Cícero Krupp da. Benefício de prestação continuada aos imigrantes e a decisão do recurso extraordinário 587970 do STF: direito ou calvário? Revista Eletrônica Direito e Política, Programa de Pós-Graduação Stricto Sensu em Ciência Jurídica da UNIVALI, Itajaí, v.13, n.3, $3^{\circ}$ quadrimestre de 2018. Disponível em: www.univali.br/direitoepolitica - ISSN 1980-7791

no RE 587.970, reconheceu a repercussão geral da discussão sobre a possibilidade de conceder a estrangeiros residentes no país o benefício assistencial previsto no artigo 203, inciso $\mathrm{V}$, da Constituição Federal. O referido recurso extraordinário ajuizado pelo INSS passou por julgamento no dia 20/04/2017, ao que o recurso foi desprovido e fixou-se a seguinte ementa: ASSISTÊNCIA SOCIAL - ESTRANGEIROS RESIDENTES NO PAÍS- ARTIGO 203, INCISO V, DA CONSTITUIÇÃO FEDERAL ALCANCE. A assistência social prevista no artigo 203, inciso $\mathrm{V}$, da Constituição Federal beneficia brasileiros natos, naturalizados e estrangeiros residentes no País, atendidos os requisitos constitucionais e legais. [...]. TRF4a Região. Recurso Cível no 5013915-72.2016.4.04.7000/PR, Relator Vicente de Paula Ataíde Junior)

Sem a necessidade de grandes esforços, é fácil constatar a incompatibilidade do ato administrativo que denega o BPC, pois não obstante as normas de Direito Público Internacional e a legislação interna observa-se que não há qualquer justificativa para a concessão do BPC somente aos nacionais, como fez o Decreto 6.214/2007 (art. 70). A exclusão do imigrante de um direito fundamental humano mostra-se incoerente com o nosso ordenamento jurídico, isso porque, não pode um decreto que regulamenta um benefício, diminuir seu rol de potenciais beneficiários estabelecido constitucionalmente por um critério de nacionalidade. Assim, ainda que tenha o estrangeiro conquistado direito à percepção do benefício que Ihes trarão em parte dignidade humana, por outro lado, o caminho a ser percorrido é árduo até o momento da concessão, tornando essa caminhada em um verdadeiro calvário.

\section{CONSIDERAÇÕES FINAIS}

A concessão do benefício assistencial aos imigrantes é tema atual e de grande relevância social. Nesse viés, a decisão proferida pelo STF no RE 587970 estabeleceu que o artigo 203, inciso V, da Constituição, deve ser interpretado de forma a conferir proteção a quem for incapaz de garantir sua subsistência, independendo, portanto, de ser o indivíduo imigrante ou brasileiro. Da mesma forma, estabelece o artigo $5^{\circ}$ de nossa Carta Maior, o princípio da igualdade e o tratamento isonômico entre brasileiros e estrangeiros residentes no País. Destacou ainda a decisão proferida no 587970 do STF que nem a Constituição, nem a LOAS preveem a nacionalidade como critério para a concessão do benefício. Somado a 
DINIZ, Silvania Aparecida; LUZ, Cícero Krupp da. Benefício de prestação continuada aos imigrantes e a decisão do recurso extraordinário 587970 do STF: direito ou calvário? Revista Eletrônica Direito e Política, Programa de Pós-Graduação Stricto Sensu em Ciência Jurídica da UNIVALI, Itajaí, v.13, n.3, $3^{\circ}$ quadrimestre de 2018. Disponível em: www.univali.br/direitoepolitica - ISSN 1980-7791

isso, acresceram que o Brasil é signatário de tratados internacionais (Declaração Universal dos Direitos Humanos, Convenção Americana de Direitos Humanos, etc.), e incorporou no seu ordenamento jurídico com status constitucional a Convenção de Nova Iorque, através do Decreto presidencial no 6.949, de 25 de agosto de 2009, nos termos do $\S 3^{\circ}$ do artigo $5^{\circ}$ da CF, vedando expressamente qualquer forma de discriminação em relação às pessoas com deficiência, onde se vê que a Constituição Federal reforçou essa impossibilidade de discriminação na assistência social tão somente pelo fato da nacionalidade.

É certo também que o dever de solidariedade social transcende o vínculo da nacionalidade, principalmente em observância de direitos fundamentais e desse modo, foi possível constatar a legitimação dos imigrantes no Brasil à percepção do Benefício de Prestação Continuada (BPC), obviamente quando preenchidos os requisitos legais (idade e deficiência). Entretanto, o caminho percorrido torna-se um calvário, pois encontram barreiras na aferição do critério de nacionalidade no ordenamento jurídico interno, tanto no âmbito administrativo e judicial para usufruí-los, mesmo que sejam direitos consagrados constitucionalmente, na legislação interna e nos tratados internacionais.

Embora o Supremo Tribunal Federal, tenha se pronunciado sobre a temática de repercussão geral, assegurando aos estrangeiros o direito à percepção do BPC, a negativa administrativa persiste mesmo se mostrando injustificada, pois baseiase em uma instrução normativa e um decreto parlamentar, sobrepondo-se a conteúdos constitucionais, persiste também de forma cruel na ofensa aos direitos fundamentais humanos, bem como, à recepção pelo Estado aos tratados internacionais de direitos humanos e direitos sociais.

Razão disso foi possível concluir ao final que é preciso uma ampliação das políticas públicas sociais, com maior interação entre os poderes do Estado, além da necessidade de criação de estrutura para integração da aplicação das decisões judiciais no âmbito da Previdência Social, a fim de combater a discriminação entre nacionais e imigrantes.

A pesquisa é embrionária, mas tem o fito de fomentar discussões acerca da temática, e firmar a posição no sentido da possibilidade da concessão 
DINIZ, Silvania Aparecida; LUZ, Cícero Krupp da. Benefício de prestação continuada aos imigrantes e a decisão do recurso extraordinário 587970 do STF: direito ou calvário? Revista Eletrônica Direito e Política, Programa de Pós-Graduação Stricto Sensu em Ciência Jurídica da UNIVALI, Itajaí, v.13, n.3, $3^{\circ}$ quadrimestre de 2018. Disponível em: www.univali.br/direitoepolitica - ISSN 1980-7791

administrativa do BPC ao imigrante, sem a necessidade da intervenção do Poder Judiciário, bastando o cumprimento por parte do órgão gestor da Previdência Social, do princípio fundamental constitucional e humano de isonomia e dignidade humana, obedecendo a hierarquia das leis.

\section{REFERÊNCIAS DAS FONTES CITADAS}

ACNUR (Org.). Dados sobre refúgio no Brasil: Balanço até abril de 2016. Disponível em: < http://www.acnur.org/portugues/recursos/estatisticas/dadossobre-refugio-no-brasil/>. Acesso em: 06 fev. 2018.

BANDEIRA, Luiza. Sem programa específico para refugiados, Brasil põe centenas de sírios no Bolsa Família. (2015). Disponível em: < http://www.bbc.com/portuguese/noticias/2015/10/151013_bolsa_familia_sirios_ lab> Acesso em: 12. Mar.2018.

. BRASIL. Constituição (1988). Constituição da República Federativa do Brasil. Brasília, DF: Senado Federal: Centro Gráfico, 1988.

BRASIL. Decreto no 6.214, de 26 de setembro de 2007. Regulamenta - Benefício de Prestação Continuada da Assistência Social Devido à Pessoa Com Deficiência e Ao Idoso de Que Trata A Lei no 8.742, de 7 de dezembro de 1993, e a Lei № 10.741, de $1^{\circ}$ de outubro de 2003, Acresce Parágrafo ao Art. 162 do Decreto no 3.048, de 6 de Maio de 1999, e Dá Outras Providências. Brasília, Disponível em: < http://www.planalto.gov.br/ccivil_03/_ato20072010/2007/decreto/d6214.htm >. Acesso em: 08 jan. 2018.

BRASIL. Decreto no 7.617, de 17 de novembro de 2011. Altera $O$ Regulamento do Benefício de Prestação Continuada, Aprovado Pelo Decreto no 6.214, de 26 de setembro de 2007. Brasília, Disponível em: < http://www.planalto.gov.br/ccivil_03/_Ato2011-2014/2011/Decreto/D7617.htm >. Acesso em: 06 jan. 2018.

BRASIL. Decreto no 50.215, de 28 de janeiro de 1961. Promulga $A$ Convenção Relativa Ao Estatuto dos Refugiados, Concluída em Genebra, em 28 de julho de 1951. Brasília, Disponível em: < http://www.planalto.gov.br/ccivil_03/decreto/1950-1969/D50215.htm.>. Acesso em: 04 jan. 2018.

Disponível

BRASIL. Declaração Universal dos Direitos do Homem (1948). <http://www.mp.go.gov.br/portalweb/hp/7/docs/declaracao_universal_dos_direi tos_do_homem.pdf> Acesso em: 06 fev. 2018.

BRASIL. Lei no 6.815, de 19 de agosto de 1980. Define a Situação Jurídica do Estrangeiro no Brasil, cria o Conselho Nacional de Imigração. Disponível em: < https://tinyurl.com/zrp3wtt >. Acesso em: 12. mar. 2017. 
DINIZ, Silvania Aparecida; LUZ, Cícero Krupp da. Benefício de prestação continuada aos imigrantes e a decisão do recurso extraordinário 587970 do STF: direito ou calvário? Revista Eletrônica Direito e Política, Programa de Pós-Graduação Stricto Sensu em Ciência Jurídica da UNIVALI, Itajaí, v.13, n.3, $3^{\circ}$ quadrimestre de 2018. Disponível em: www.univali.br/direitoepolitica - ISSN 1980-7791

BRASIL. Lei no 8.742, de 07 de dezembro de 1993. Dispõe sobre A Organização da Assistência Social e Dá Outras Providências. Brasília, DF, Disponível em: < http://www.planalto.gov.br/ccivil_03/leis/L8742compilado.htm >. Acesso em: 06 jan 2018.

BRASIL. Lei no 9.474, de 22 de julho de 1997. Define mecanismos para a implementação do Estatuto dos Refugiados de 1951, e determina outras providências. Disponível em: < http://www.planalto.gov.br/ccivil_03/Leis/L9474.htm >. Acesso em: 07 jan 2018.

BRASIL. Lei no 10.836, de 9 de janeiro de 2004. Cria o Programa Bolsa Família e dá outras providências.. Disponível em: < http://www.planalto.gov.br/ccivil_03/_ato2004-2006/2004/lei/l10.836.htm >. Acesso em: 12.mar. 2018.

BRASIL. Lei no 13.146, de 06 de julho de 2015. Institui A Lei Brasileira de Inclusão da Pessoa Com Deficiência (estatuto da Pessoa Com Deficiência). Brasília, Disponível em: < http://www.planalto.gov.br/ccivil_03/_ato20152018/2015/lei/l13146.htm >. Acesso em: 13 mar 2018.

Disponível

BRASIL. Ministério do Desenvolvimento Social e Combate à Fome. <http://www.mds.gov.br/webarquivos/legislacao/bolsa_familia/instrucoes_opera cionais/2014/IOn02\%20conjunta\%20SNAS_SENARC_PETI_final_05_08_2014.pd f> Acesso em: 06 fev 2018.

BRASIL. Ministério do Desenvolvimento Social e Agrário; Instituto Nacional do Seguro Social. Portaria, que regulamenta regras e procedimentos de requerimento, concessão, manutenção e revisão do Benefício de Prestação Continuada da Assistência Social - BPC. Disponível em: <http://sislex.previdencia.gov.br/paginas/64/MDSA-INSS/2017/1.htm> Acesso em: 06 fev 2018.

BRASIL. Instituto Nacional do Seguro Social. Portaria, estabelece normas e procedimentos para a operacionalização do Benefício de Prestação Continuada devido à pessoa portadora de deficiência e ao idoso e dá outras providências. Disponível em: <http://www.portalinclusivo.ce.gov.br/phocadownload/legislacaoidoso/resolucao \%20inss\%20n.\%20435.pdf> Acesso em: 06 fev 2018.

BRASIL - Ministério Público Federal. Ação civil pública no $0023528-$ 28.2010.4.03.6100(2010). Disponível em: <www.prsp.mpf.gov.br/prdc/salade-imprensa/pdfs-das-noticias/ACP_Palestinos.pdf> Acesso em: 07 jan. 2018

. BRASIL. Tribunal Regional Federal da 4$^{a}$ Região - Seção Judiciária de Canoas/RS. (2015) Disponível em: <https://www2.jfrs.jus.br/justicafederal-em-canoas-rs-concede-beneficio-assistencial-a-refugiado-palestino/> Acesso em: 12 Mar 2018. 
DINIZ, Silvania Aparecida; LUZ, Cícero Krupp da. Benefício de prestação continuada aos imigrantes e a decisão do recurso extraordinário 587970 do STF: direito ou calvário? Revista Eletrônica Direito e Política, Programa de Pós-Graduação Stricto Sensu em Ciência Jurídica da UNIVALI, Itajaí, v.13, n.3, $3^{\circ}$ quadrimestre de 2018. Disponível em: www.univali.br/direitoepolitica - ISSN 1980-7791

BRASIL. Tribunal Regional Federal da $4^{\mathbf{a}}$ Região. Jurisprudência no 5013915-72.2016.4.04.7000/PR. Relator: Juiz Federal VICENTE DE PAULA ATAÍDE JUNIOR. Curitiba, PR, 15 de fevereiro de 2018. Diário Eletrônico da Justiça Federal. Curitiba, 15 fev. 2018. Disponível em: < https://jurisprudencia.trf4.jus.br/pesquisa/inteiro_teor.php?orgao=4\&documento $=9428798$ \&termosPesquisados $=I G J w Y y B \mid c 3 R y Y W 5 n Z W l y b y A>$. Acesso em: 13 mar 2018.

BRASÍLIA. SUPREMO TRIBUNAL FEDERAL. Concessão de benefício assistencial a estrangeiros residentes no Brasil. Disponível em: http://stf.jus.br/portal/jurisprudenciarepercussao/verAndamentoProcesso.asp?in cidente $=2621386 \&$ numeroProcesso $=587970 \&$ classeProcesso $=$ RE $\&$ numeroTema $=$ 173>. Acesso em: 06 jan 2018.

CASTRO, Carlos Alberto Pereira de; LAZZARI, João Batista. Manual de Direito Previdenciário. 16a ed. Rio de Janeiro: Forense, 2014.

.CONARE - DADOS SOBRE REFUGIO NO BRASIL - Disponível em: <http://www.acnur.org/portugues/dados-sobre-refugio/dados-sobre-refugio-nobrasil/>. Acesso em: 08 abr 2018

Convenção da Organização de Unidade Africana(OUA). 1969. Disponível em: <www.acnur.org/t3/portugues/.../documentos/?tx...> Acesso em : 06 fev. 2018.

Disponível

Convenção Relativa ao Estatuto dos Refugiados (1951). 1951. http://www.acnur.org/fileadmin/scripts/doc.php?file=fileadmin/Documentos/port ugues/BDL/Convencao_relativa_ao_Estatuto_dos_Refugiados > . Acesso em: 06 fev. 2018.

http://. Declaração de Cartagena. 1984. Disponível em: ugues/BD_Legal/Instrumentos_Internacionais/Declaracao_de_Cartagena $>$.

Acesso em: 06 fev 2018.

GARCIA, Gustavo Felipe Barbosa. Curso de Direito da Seguridade Social: Previdência Social, Saúde e Assistência Social. $3^{a}$ ed. Rio de Janeiro: Forense, 2017.

JUBILUT, Liliana Lyra. O Direito Internacional dos Refugiados: e sua Aplicação no Ordenamento Jurídico Brasileiro. São Paulo: Método, 2007.

MARTINEZ, Wladimir Novaes. Curso de Direito Previdenciário. São Paulo: Ltr, 2010.

MEZZADRA, Sandro. Diritto di Fuga. Migrazioni, cittadinanza, globalizzazione. Verona: Ombre Corte, 2006. 
DINIZ, Silvania Aparecida; LUZ, Cícero Krupp da. Benefício de prestação continuada aos imigrantes e a decisão do recurso extraordinário 587970 do STF: direito ou calvário? Revista Eletrônica Direito e Política, Programa de Pós-Graduação Stricto Sensu em Ciência Jurídica da UNIVALI, Itajaí, v.13, n.3, $3^{\circ}$ quadrimestre de 2018. Disponível em: www.univali.br/direitoepolitica - ISSN 1980-7791

ROCHA, Daniel Machado; SAVARIS, José Antônio Savaris. Curso de Direito Previdenciário. Curitiba: Alteridade, 2014.

SANTOS, Marisa Ferreira dos. Direito Previdenciário Esquematizado. 3. ed. São Paulo: Saraiva, 2013.

Recebido em: 09/10/2018

Aprovado em: 20/10/2018 